\title{
THE EFFECTIVENESS OF CLINICAL LEARNING MODULE ON COMPETENCY ACHIEVEMENT OF NURSING STUDENTS
}

\author{
Arif Helmi Setiawan ${ }^{1 *}$, Siti Nurjannah ${ }^{1}$, Nur Muji Astuti ${ }^{2}$ \\ 1) Faculty of Nursing and Midwifery Nahdlatul Ulama University Surabaya \\ 2) Hang Tuah Surabaya Health Sciences Institute \\ Email*: arif@Unusa.ac.id
}

\begin{abstract}
Introduction: Clinical learning is a very important component for nursing students to integrate theoritical with skills in real settings. However, the reality revealed that the achievement of student competency is still not fulfilled yet; this is due to the unstructured interaction between students and mentors. The purpose of this study was analyzed the competence of the clinical learning module on the competency achievement of nursing student. Methods: This research is a quasi-experiment with the pretest-posttesttwogroup research design. Research samples of students in two nursing school in Surabaya who met the criteria of 50 respondents as a treatment group and 50 respondents as a control group. The research instrument used questionnaires and clinical learning modules as well as competency achievement books. Data analysis used Wilcoxon sign ranks test and Mann Whitney test with $\alpha \leq 0,05$.Results: The results of statistical tests in the control group obtained $P$ value 0.14 showed there were differences in achievement of competencies before and after, in the treatment group obtained $P$ value 0.000 which means that there were differences in achievement of competencies before and after using the learning module, and the results of Mann Whitney Test obtained P 0.000 , means there is an influence of the clinical learning module on the achievement of the competence of nursing students.Conclusions: Nursing clinic learning requires interaction between students and mentors so that with this clinical learning module can effectively improve the achievement of the competence of nursing students.
\end{abstract}

Keywords: Competency achievement, Clinical learning module, Nursing

\section{INTRODUCTION}

Learning in the hospital is an applicative learning to get real experience for nursing students. The nursing clinical learning process is an important component to prepare students through direct experience as a process of transforming students into skilled nurses, as well as providing opportunities to adapt according to their roles, so that interactive and inspirational learning methods are needed. For students, Clinical learning is aimed to be active in achieving competence (Akbar 1996, Wicaksono 2014).

Various kinds of innovative learning methods can be developed by educational institutions such as experiential learning found in student centered oriented models. This learning through four stages of the cycle namely concrete experience, reflective observation, abstract conceptualization and active experimentation (AY \& Kolb, 2005).

The implementation of clinical learning for nursing students at the hospital is still not structured well so that there are many problems such as communication impediments of students and mentors, anxiety due to the interaction with the new environment in the room that causes students to feel physically and psychologically burdened. This causes students to fail to apply the nursing process so that it affects clinical learning outcomes(Hardisman 2009, Atti et al. 2015).

The existence of several learning methods can influence the results of student clinical learning. The provision of bed side teaching methods can improve student 
competence. Experiential learning can build real skills, and can improve the mind skills of respectful students to respect and accept others' empathy and ability to cooperate. Besides, experiential learning using modules can increase the average value of learning outcomes in the cognitive, affective and psychomotor aspects; and learning activities (Puji, 2011). The results of a study by Setiawan, Yusuf, and Nihayati 2017, stated that experimental clinical learning had an effect on the learning outcomes of nurses in emergency department nurses.

Experiential clinical learning models are influenced by two direct factors, namely the characteristics of students and learning behavior and two indirect factors, namely the observation process and the thinking process. While, the clinical learning process is influenced by the characteristics of students, the role of clinical mentors, management, the ratio of students and clinical advisers, and the competence of clinical mentors. In addition to hospital procedures and regulations, collaborative arrangements with hospitals and care staff as well as ethical reasons as students to help patients are some obstacles faced by students during clinical learning (Rika 2009, Atti et al. 2015, Setiawan et al. 2017).

Efforts to improve the achievement of nursing clinical learning are done through structuring clinical learning management including the ability and competence ofmentors , completeness of facilities, curriculum, guidance arrangements, and collaboration with practice sites. The arrangement of the management of experiential clinical learning is well carried out through a structured experiential learning process using clinical learning modules so that students and mentor are engaged in learning contracts during nursing practice in the hospital so that competency targets can be achieved(Reilly \& Obermann, 2002). The purpose of this study was analyzed the competence of the clinical learning module on the competency achievement of nursing student.

\section{METHODS}

This research design is quasiexperiment with the pretest-posttest two group design. The research sample was students in two nursing school in Surabaya who met the research inclusion criteria including the students of profession and medical surgical competence. The students were then devided into 50 respondents as the control group and 50 respondents as the treatment group. The variable in this study is the applicationof clinical learning modules that is the handbook applied by the students during clinical instruction through 4 stages, namely concrete experience, ebservation, conceptual thinking and active actions and the dependent variable is the achievement of student medical surgical competencies. The independent variables are the application of clinical learning modules and the dependent variable is the achievement of competencies. The intervention procedure are:

1. Before collecting the data, a Focus Group Discussion (FGD) was done for the hospital's mentors about the use of clinical learning modules.

2. The respondents were given an explanation of the research and asked for their approval as the subjects of the research and to fill out the questionnaire

3. The respondents were devided into namely control group and treatment group

4. The treatment group was given an explanation of the use of the clinical learning module

5. The competency of both groups were measured after practicing for 2 weeks (pre test)

6. During the next 2 weeks, the intervention group applied the clinical learning module through 4 stages namely concrete experience, observation, conceptual thinking, active action

7. After 2 weeks the control and treatment groups were measured by the mentors for their competency achievements as a post test 
This study used a demographic data questionnaire consisting of 10 question items, and the instrument of competency achievement contained in the clinical learning module, which were measured based on the number of competency targets achieved by the respondent

The ethical clearance obtained from Hang Tuah Health Sciences Institute as one of the research institution with the researchs ethics number PE/95/VIII/2018/KEPK/SHT.The research analysis used Wilcoxon sign ranks test and Mann Whitney test with significance level $\alpha$ (0.05).

\section{RESULTS}

Statistical test results of this study can be seen in the table 1 which shows that in the control group obtained $\mathrm{P}$ value 0.014 $<0.05$ which means that there are differences in achievement of competencies before and after, in the treatment group obtained $\mathrm{P}$ value $0.000<0.05$ which means there are differences in achievement of competencies before and after using the learning module.

The test results in table 2 above shows that in both groups the control and treatment groups using clinical learning modules found differences in the achievement of significant pre and post results, but on the mean ranks in table 2 there was a difference in the treatment group mean ranks (62.98) is greater than the control group (39.02).

\section{DISCUSSIONS}

Achievement of competency is a measuring tool of what is obtained by a person in completing the learning process, whether structured or not. In the education system the success of output is influenced by the process in this case learning and input that is the characteristics of students, this is consistent with the results of research that clinical learning outcomes are directly influenced by experience-based clinical learning while the learning process is directly influenced by student characteristics and learning behavior (Pannen 2001, Setiawan et al. 2017). According to Wicaksono 2014, clinical learning is influenced by the knowledge, attitudes, talents, and motivation of students. Adequate number and type of equipment also influences clinical learning, as well as environmental factors in clinical

Table 1.The Achievement of students'competencies before and after seen in the control and treatment group in two nursing school inSurabaya, 2018

\begin{tabular}{lcccccc}
\hline \multicolumn{1}{c}{ component variable } & \multicolumn{5}{c}{$\begin{array}{c}\text { Analysis } \\
\text { Wilcoxon }\end{array}$} \\
\cline { 3 - 7 } & & \multicolumn{2}{c}{ Treatment } & & Control \\
\hline $\begin{array}{l}\text { Achievement } \\
\text { competencies }\end{array}$ & of & $\mathrm{Z}$ & $\mathrm{P}$ Value & $\mathrm{Z}$ & $\mathrm{P}$ Value \\
\cline { 4 - 7 } & & -4.339 & 0.000 & -2.467 & 0.014 \\
\hline
\end{tabular}

Table 2. The Effectiveness of clinical learning modules on the achievement of nursing students' competencies in two nursing school in Surabaya, 2018

\begin{tabular}{lllll}
\hline component variable & \multicolumn{3}{c}{$\begin{array}{c}\text { Analysis } \\
\text { Mann Whitney }\end{array}$} \\
\hline Achievement of Competency & \multicolumn{2}{c}{ mann whitney } & \multicolumn{2}{c}{ Mean ranks } \\
\cline { 2 - 5 } & $\mathrm{Z}$ & $\begin{array}{l}\mathrm{P} \\
\text { value }\end{array}$ & treatment & control \\
\cline { 2 - 5 } & & 0.000 & 62.98 & 38.02 \\
& 4.361 & & & \\
\hline
\end{tabular}


learning are influenced by the attitude and manner of instructors, cooperative patients, student motivation. Characteristics of students influence the process to experience an event such as age, education, environment(Sadirman, 2006). The learning environment is the elements that come from outside of the students, such as: the social environment of education, community, family, natural environment, instrumental factors, and material factors, the organizational culture and learning components besides that an effective learning environment must have experienced personnel in providing the right learning for students(Anderson 2011,Muhhibin 2012, Elizabeth et al, 2016, Petros et al. 2016), The clinical learning environment should be carefully assessed to reduce nursing students' stress and anxiety from clinical practice (Kim \& Yang, 2015)This is supported by the research Ahmad and Anwar 2018 thatthat the majority of the students had positive perceptions of the clinical learning environment, supervision, and nurse teachers and the characteristics of respondents who are purely students of nursing department so that respondents have had previous experience during education in academic. Besides, the environment of the residence in the control group is $66 \%$ and treatment group is $78 \%$ support the clinical learning process, the distance to the practice in the treatment group is closer $<5 \mathrm{Km}$ by $50 \%$ and supporting facilities as a practice place by $82 \%$ in the control group and $92 \%$ in the treatment group.

In table 2 there was a difference in the treatment group mean ranksis greater than the control group. This is due to the treatment group was being given a clinical learning module for students during practice so that the interaction between students and mentors is more structured. Clinical staff attitudes influenced students' clinical learning experiences and outcomes (Kristina Mikkonena Satu Eloa, Maria Kuivilaa, \& Kääriäinena, Maria Tuomikoskib, 2016). Supervisors as role models will provide more knowledge transfer according to the experience in the hospital. This is supported by $90 \%$ of mentors in the treatment group who have played a good role. Clinical learning for students is an experience-based learning process. This learning model refers to the learning process that involves students directly in the problem or the material which are being studied.

According to Kolb 1984, learning is the process of constructing knowledge through the transformation of experience. The module used during this study was developed from an experiential learning model because this learning utilizes new experiences and student reactions to their experiences to build understanding and transfer of knowledge, skills, and attitudes. Ernawati 2013 stated that the conceptual method in nursing clinic guidance can improve the achievement of student competencies in nursing clinical practice. Lee and Lapum 2018 said thatthe engagement students in the design of themebased Post Clinical Conference provided insight into pedagogies that can enrich undergraduate nursing students' clinical learning. The factors influencing the learning experience come from the planning of educational programs made, the quality and quantity of relationships and interactions between students and mentors, the students' satisfaction with the supervisory relationship and the role of NT depend on how supervision in the clinical practice and in the simulation laboratory is organized (Cremonini, Ferri, \& Artioli, 2015). The discrepancy between teaching styles and learning styles has been found to have serious consequences. So the learning model must be used to meet learning needs (Rassool 2007). This results are consistent with Kamolo and Krchn 2017 which use module on their student used preceptorship method that can improve their knowledge and skills. The intens of relationship in preceptorship effect on the control of medical competence that affects clinical performance, motivation to learn more and be able to develop critical thinking(Tursina, Safaria, \& Mujidin, 2016). 
The limitation of the study is due to the fact that the medical surgical practice was done only in 4 weeks which were devided into two section. The first 2 weeks was to evaluate the initial competency achievement (pre test) and the next 2 weeks was to evaluate the competency achievement after using the clinical learning module (post test).

\section{CONCLUSIONS}

Clinical learning modules can effectively improve the achievement of the competence of nursing students. Therefore this module can be used to assist nursing students while carrying out nursing practice inthe hospital

For further researchers this module can be developed as a medium of learning in the community nursing and other nursing competencies.

\section{REFERENCES}

Ahmad, N., \& Anwar, N. H. K. A. (2018). Nursing Students and Clinical Instructors' Perceptions of Clinical Learning Environments, Supervision, and Teaching. International Journal of Care Scholars, 1. Retrieved from http://journals.iium.edu.my/ijcs/index.p hp/ijcs/article/view/38

Akbar. (1996). Pengalaman Belajar Klinik dan Pengalaman Belajar pada Pendidikan Dokter Gigi. PPGI, 45.

Anderson, L. (2011). A Learning Resource for Developing Developing Effective Mentorship in Practice. Nursing Standard, 25.51. Retrieved from https://search.proquest.com/openview/3 71732bfd2599b9f387eb408aabeb1f3/1? pq-origsite $=$ gscholar $\&$ cbl $=30130$

Atti, Y., Punaj, S., Degeng, I., \& Rudianto, A. (2015). Pengaruh Strategi Pembelajaran dan Gaya Kognitif terhadap Prestasi Belajar Aplikasi Proses Keperawatan pada Pembelajaran Klinik Keperawatan. Jurnal Pendidikan Humaniora, 1. Retrieved from http://training.um.ac.id/ojs/index.php/jp h/article/view/4826

AY, K., \& Kolb, D. (2005). Learning Styles And Learning Spaces: Experiential Learning In Higher Education. Academy of Management Learning \& Education, 4. Retrieved from https://journals.aom.org/doi/abs/10.5465 /AMLE.2005.17268566

Cremonini, V., Ferri, P., \& Artioli, G. (2015). Nursing students' experiences of and satisfaction with the clinical learning environment: the role of educational models in the simulation laboratory and in clinical practice. Acta Biomedica, 86. Retrieved from http://mattioli1885journals.com/index.p hp/actabiomedica/article/view/5161

Ernawati, S. (2013). Pengaruh penggunaan metode konseptual dalam bimbingan praktek klinik keperawatan terhadap pencapaian kompetensi. Universitas Sebelas Maret. Retrieved from https://eprints.uns.ac.id/4219/

Hardisman. (2009). Model Bimbingan pada Pendidikan Klinik dan Relevansinya pada Pendidikan Kedokteran dan Kesehatan di Indonesia. Majalah Kedokteran Andalas. Retrieved from http://jurnalmka.fk.unand.ac.id/index.ph p/art/article/view/53

Kamolo, E., \& Krchn, B. (2017). A Critical Review of Preceptor Development for Nurses Working with Undergraduate Nursing Students. International Journal Of Caring Sciences, 10(2), 1089-1100. Retrieved from http://www.internationaljournalofcaring sciences.org/docs/50_kamolo_special_1 0_2.pdf

Kim, E. Y., \& Yang, S. H. (2015). Effects of Clinical Learning Environment on Clinical Practice Stress and Anxiety in Nursing Students. Journal of Korean Academy of Nursing Administration, 4, 417-425. Retrieved from https://synapse.koreamed.org/search.ph p? where $=$ aview\&id=10.11111/jkana. 20 15.21.4.417\& $\operatorname{code}=0163 \mathrm{JKANA} \& \mathrm{vmo}$ $\mathrm{de}=\mathrm{FULL}$ 
Kolb. (1984). Experiential Learning. New Jersey: Prentice-Hall Inc.

Kristina Mikkonena Satu Eloa, H., Maria Kuivilaa, A., \& Kääriäinena, Maria Tuomikoskib, M. (2016). Culturally and linguistically diverse healthcare students' experiences of learning in a clinical environment: A systematic review of qualitative studies. International Journal of Nursing Studies, 54, 173-187. Retrieved from https://www.sciencedirect.com/science/ article/pii/S0020748915001984

Lee, C. T., \& Lapum, J. L. (2018). StudentGuided, Theme-Based Postclinical Conference to Enhance Student Involvement in Clinical Learning. Journal of Nursing Education, 57. Retrieved from https://www.healio.com/nursing/journal s/jne/2018-6-57-6/\%7B4d32912b-88df4ec8-bb76-007c06757187\%7D/studentguided-theme-based-postclinicalconference-to-enhance-studentinvolvement-in-clinical-learning

Muhhibin, S. (2012). Psikologi Belajar. Jakarta: Raja Grapindo.

Pannen, P. (2001). Pendidikan sebagai Sistem. Jakarta: PAU-PPAI, Universitas Terbuka.

Petros, P., Koreli, A., Chrysoula, T., Katsoulas, T., \& Koutsopoulou, V. (2016). Nursing Students Participation And Degree Of Involvement In Essential Nursing Activities During Their Clinical Practice In Hospital Setting. International Journal Od Caring Science, 9. Retrieved from http://www.internationaljournalofcaring sciences.org/docs/27_Papagiorgis_origi nal_9_2.pdf

Puji, L. (2011). Efektifitas Metode Pembelajaran Bed Side Teaching terhadap Kemampuan Psikomotor Mahasiswa D3 Kebidanan Bakti
Husada. Jurnal Kesehatan, 7. Retrieved from http://saifulwhn.lecture.ub.ac.id/files/20 11/11/Metode-pembelajaran-BedSideTeaching.pdf

Rassool, G. . (2007). Learning Style Preferences Of Undergraduate Nursing Students, Nursing Standard. Public Health Database. Retrieved from http://docplayer.net/59558138-Aquantitative-investigation-into.html

Reilly, D. E., \& Obermann, M. . (2002). Pengajaran Klinis dalam Pendidikan Keperawatan (2nd ed.). Jakarta: EGC.

Rika, E. (2009). Pendidikan Keperawa. Medan: USU Press.

Sadirman, A. (2006). Interaksi dan Motivasi Belajar Mengajar. Jakarta: PT. Rajagrafindo Persada.

Setiawan, A., Yusuf, A., \& Nihayati, H. (2017). Pengembangan Model Pembelajaran Klinik Keperawatan Eksperiential Terhadap Capaian Pembelajaran Klinik Keperawatan Gawat Darurat Bagi Mahasiswa Ners. Unusa: The Journal of Health Sciences. Retrieved from http://journal.unusa.ac.id/index.php/jhs/ article/view/394

Tursina, A., Safaria, T., \& Mujidin. (2016). Pengaruh Bimbingan Preceptorship Model Kognitif Sosial Terhadap Peningkatan Kompetensi Klinik pada Mahasiswa. PSIKOPEDAGOGIA, 5(1), 79-87. Retrieved from www.journal.uad.ac.id/index.php/PSIK OPEDAGOGIA/article/view/4593

Wicaksono. (2014). Pengembangan Pembelajaran Klinik Berbasis Evaluasi Mutu Pada Jurusan Akupunktur Poltekkes Kemenkes Surakarta. Jurnal Terpadu Ilmu Kesehatan, 3. Retrieved from jurnal.poltekkessolo.ac.id/index.php/Int/article/view/84 